\title{
Investigating the Effect of Ozone on the Biodegradability of Distillery Wastewater
}

\author{
G.O. Sigge ${ }^{*}$, J. Green ${ }^{1}$, K.R. du Plessis ${ }^{2}$ and T.J. Britz ${ }^{1}$
}

(1) Department of Food Science, Private Bag X1, Stellenbosch University, Matieland, 7600, Republic of South Africa

(2) ARC Infruitec-Nietvoorbij, Private Bag X5026, Stellenbosch, 7599, Republic of South Africa

Submitted for publication: May 2007

Accepted for publication: July 2007

Key words: activity test, chemical oxygen demand (COD), distillery wastewater, ozone, upflow anaerobic sludge blanket (UASB) granules

\begin{abstract}
The effect of ozonation on wine distillery wastewater was investigated firstly by monitoring the effect of ozonation on the composition of the wastewater and, secondly, by investigating its effect on the biodegradability of the wastewater. An average COD reduction of $271 \mathrm{mg}$ COD.g $\mathrm{O}_{3}^{-1}$ was found for wastewater from a distillery pond system. Stable microbial populations, which are found in upflow anaerobic sludge blanket (UASB) granules, were used to determine the toxic effect of wastewater on microbial activity. Granule activity was measured in terms of the rate of biogas and methane production, as well as cumulative biogas volume. Low ozone doses (200 to $400 \mathrm{mg}$ $\left.\mathrm{O}_{3} \cdot \mathrm{L}^{-1}\right)$ increased granule activity in terms of biogas, methane production, and cumulative gas volumes. Distillery wastewater reduced the activity of granules, most likely due to the presence of polyphenols and other recalcitrant compounds in the distillery wastewater.
\end{abstract}

\section{INTRODUCTION}

The production of ethanol from wines by distillation processes results in a high-strength acidic wastewater (Beltrán et al., 2000). Wine distillery wastewater (DWW) typically has a high content of suspended solids and contains residual organic acids, soluble proteins, carbohydrates, as well as various inorganic compounds (Water Research Commission, 1993; Van Schoor, 2000). Distillery wastewater is acidic ( $\mathrm{pH} 3.5$ - 5.0) and is characterised by a high organic content (sugars, alcohol, phenols and polyphenols, and lipids), with a chemical oxygen demand (COD) in the range of 10 000 to 60000 mg.L-1 (Benitez et al., 1999; Martín et al., 2002). Ideally, the easiest way to dispose of these wastewaters would be by irrigation. In terms of Section 39 of the National Water Act of 1998, wastewater must either be treated prior to discharge into a water resource, or disposed of by some alternative method. If left untreated, this wastewater could potentially contaminate natural water resources and soil, as well as hinder plant growth and create odour problems. For irrigation to take place, the quality of the effluent must comply with the stipulated requirements (Department of Water Affairs and Forestry, 2004).

Current treatment options include aerobic systems, activated sludge, aeration of dam wastewaters, anaerobic bacteria, artificial wetlands, physicochemical treatments or combinations of the above treatments (Van Schoor, 2005). Distillery wastewater is chemically complex and contains a host of phenolic compounds, some of which resist biodegradation (Martín et al., 2002). In addition, refractory compounds that are present in these wastewaters, such as polyphenols, can be toxic for microorganisms (Alvarez et al., 2001). Therefore, an investigation is needed to establish which treatment methods are best suited to reach specific effluent quality goals.

A physicochemical step can be applied as a pre-treatment process when strong organic or toxic compounds are present (Wang et al., 1989). According to Gulyas et al. (1995) and Beltrán-Heredia et al. (2001), some organic compounds react rapidly with ozone $\left(\mathrm{O}_{3}\right)$. Polyphenols are aromatic compounds that are prone to attack by electrophilic agents such as $\mathrm{O}_{3}$ (Alvarez et al., 2001). The ozonation of aromatic compounds usually increases the biodegradability of the wastewater (Martín et al., 2002). Generally, the main areas where $\mathrm{O}_{3}$ is used for the treatment of wastewaters are disinfection, and the oxidation of organic and inorganic compounds, including the removal of taste, odour, colour and particles (Gottschalk et al., 2000).

Duff et al. (2002) found that an $\mathrm{O}_{3}$ treatment of $\log$ water runoff reduced COD by $22 \%$, but increased the overall biological oxygen demand (BOD). This was attributed to the conversion of the high molecular weight COD to lower molecular weight compounds capable of exerting a BOD influence. Doğruel et al. (2002) also found that pre-ozonation resulted in a limited COD removal (14\%), while McLachlan (2004) reported a 20\% reduction in the COD of cellar effluent at a concentration of $73 \mathrm{mg} \mathrm{O} \cdot \mathrm{L}^{-1}$.

Complete cleansing of wastewater pollutants will not be feasible with the adoption of a single treatment process. Combinations of chemical and biological treatments are often the only way to optimise the overall process (Andreozzi et al., 1998). Therefore, the aim of this study was to establish whether $\mathrm{O}_{3}$ could be used to improve the biodegradability of DWW. The effect of ozonation on DWW was investigated firstly by monitoring the effect

Acknowledgements: The authors thank the ARC and Winetech for financial support, as well as the staff of the Department of Food Science of Stellenbosch University and the Soil Science Section of ARC Infruitec-Nietvoorbij for technical support. This study was part of an MSc thesis done at Stellenbosch University. 
of ozonation on the composition of the wastewater and, secondly, by investigating the effect of ozonation on the biodegradability of the wastewater by using the activity of anaerobic UASB granules as an index.

\section{MATERIALS AND METHODS}

\section{Characterisation of wastewater streams from a distillery}

A distillery in the Boland region of South Africa has an existing treatment system consisting of a primary settling pond, followed by three further holding ponds (Fig. 1). The first pond receives wastewater directly from the distillery and therefore assists in settling the solids contained in the wastewater. In the second pond, aerobic aeration takes place to lower the organic load of the effluent, while the third and fourth ponds allow for further settling of suspended solids. In a study initiated by the ARC Infruitec-Nietvoorbij in 1998, a constructed wetland system was being investigated as an additional treatment method to "polish" the effluent from the final holding pond (third pond).

A preliminary study of the composition of the DWW effluent from the third pond was done to characterise the variation in DWW during the "peak season" and "off season". For the remainder of the study, DWW was obtained from the outlet of the third pond (Fig. 1) during 2004. The wastewater (unozonated and ozonated) was stored in $25 \mathrm{~L}$ drums at $-18^{\circ} \mathrm{C}$. During the investigation, drums were thawed as required and kept at $4^{\circ} \mathrm{C}$. Tap water was used to dilute the wastewater to the desired COD levels used in the trials.

\section{Ozonation of distillery wastewater}

To determine the effect of ozonation on the composition of DWW, ozone was applied by using an $\mathrm{O}_{3}$ generator (Parc Scientific, Ifafi) that produced $\mathrm{O}_{3}$ at a concentration of $4.82 \mathrm{~g} \cdot \mathrm{h}^{-1}$ and a flow rate of 4 L.min ${ }^{-1}$ as determined by the Iodometric Method (APHA, 1998). Diluted and undiluted DWW was pre-ozonated at room temperature in a glass bubble column. The glass column had a height of $104 \mathrm{~cm}$, a diameter of $10 \mathrm{~cm}$ and a volume of $2 \mathrm{~L}$. It contained two sintered discs at the top and bottom of the column. The function of the bottom sinter was to allow better gas bubble distribution, and the function of the top sinter was to reduce the loss of wastewater through foaming. The sample was poured into the bubble column and was ozonated for the predetermined time/ ozone dose combination.

In order to investigate the efficiency of ozonation on DWW with different COD loads, a dilution series of DWW was prepared. Each DWW dilution was ozonated with a $400 \mathrm{mg} \mathrm{O} \cdot \mathrm{L}^{-1}$ dose. The COD reduction in each dilution was determined to allow calculation of the $\mathrm{O}_{3}$ efficiency in terms of COD $(\mathrm{mg})$ removed per $\mathrm{mg} \mathrm{O}_{3}$ over a range of COD loads.

\section{Analytical methods}

The following wastewater parameters were monitored according to standard methods (APHA, 1998): $\mathrm{pH}$, alkalinity, total solids (TS), total suspended solids (TSS), total volatile solids (TVS) and total volatile suspended solids (TVSS). Conductivity was determined using a Hanna Instruments (HI8733) conductivity meter. The COD and orthophosphate phosphorous $\left(\mathrm{PO}_{4}^{3-}\right)$ were determined colorimetrically using a DR2000 spectrophotometer (Hach Co. Loveland, CO) and standardised procedures (APHA, 1998). The total polyphenol content was determined using the FolinCiocalteau method (Singleton \& Rossi, 1965). All analyses were done in triplicate.

The biogas composition was determined using a gas chromatograph (Varian 3300). A $0.2 \mathrm{~mL}$ sample of biogas was injected into the gas chromatograph, using helium $(\mathrm{He})$ as a carrier gas at a flow rate of $30 \mathrm{~mL} \cdot \mathrm{min}^{-1}$, with the oven temperature set at $55^{\circ} \mathrm{C}$. The gas chromatograph was equipped with a thermal conductivity detector and a $2.0 \mathrm{~m} \times 3.0 \mathrm{~mm}$ internal diameter column packed with Hayesep Q (Supelco, Bellefonte, PA) and a 80/100 mesh.

Upflow anaerobic sludge blanket (UASB) granule activity to measure wastewater toxicity

\section{$U A S B$ granule selection}

A UASB granule activity test method described by O'Kennedy (2000) and Sigge (2005) was used as an index of biodegradability. This method was chosen as it is easy to use, relatively sensitive and not time-consuming. Bacteria such as the methanogens

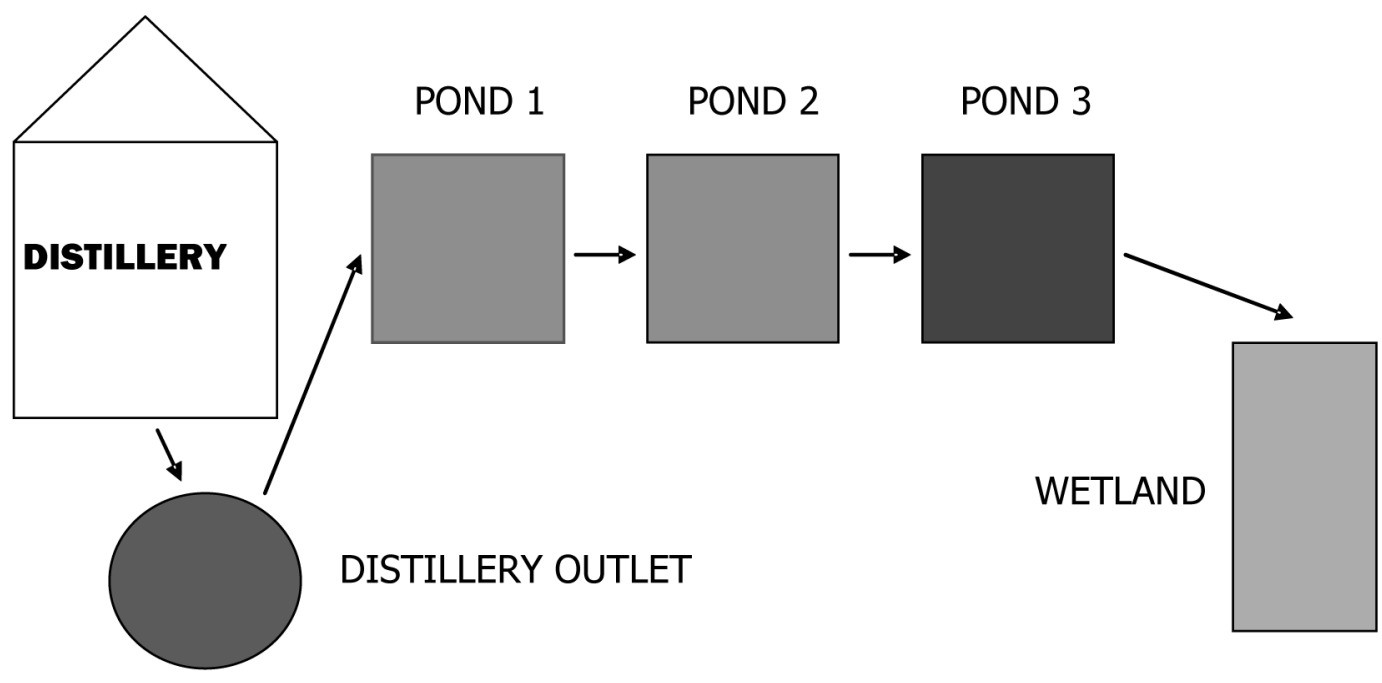

FIGURE 1

Schematic layout of the settling dams and constructed wetland at a distillery in the Boland region of South Africa. 
in UASB granules are especially sensitive to toxic compounds in wastewaters (Benitez et al., 1999). Therefore, a stable microbial population, such as that found in UASB granules, could be used to determine the toxic effect of a wastewater on the microbial activity, and thus serve as an index of biodegradability.

Activity tests were performed on UASB granules according to a method described by O'Kennedy (2000) and Sigge (2005). Granule activity was measured by the rate of production of biogas $\left(\mathrm{S}_{\mathrm{b}}\right)$ and methane $\left(\mathrm{CH}_{4}\right)\left(\mathrm{S}_{\mathrm{m}}\right)$. Granules that had been obtained from various UASB reactors and stored at $4{ }^{\circ} \mathrm{C}$ were used. The granules originated from UASB reactors at two different distilleries, a beer waste treatment plant, a fruit canning effluent plant, a winery and a mixture of these granules. The activity of the granules from the various UASB reactors was compared so as to select the most active granule set. These granules would be used in the trial to determine the effect of ozonation on the biodegradability of the DWW.

To activate the granules for the activity tests, $500 \mathrm{~g}$ of granules were incubated at $35^{\circ} \mathrm{C}$ for $48 \mathrm{~h}$ in activation media (Table 1) in a volume ratio of $1: 2$, and this was replaced with fresh activation media after $24 \mathrm{~h}$. The composition of the activation media (in mg. $\mathrm{L}^{-1}$ ) was: glucose $1000 ; \mathrm{K}_{2} \mathrm{HPO}_{4}$ 500; and urea 500. This was done to activate the metabolic activity of the various bacterial groups in the granules, which had been kept dormant at $4^{\circ} \mathrm{C}$ during storage. Once the $48 \mathrm{~h}$ activation period was completed, the granules were drained and then prepared for the trials to determine the effect of ozonation on the biodegradability of DWW.

\section{Effect of ozonation on biodegradability of $\mathrm{DWW}$}

The drained granules were divided into five $60 \mathrm{~g}$ sample portions and placed in five separate $500 \mathrm{~mL}$ Schott bottles. Each granule sample $(60 \mathrm{~g})$ was exposed to a differently ozonated (in terms of ozone dose) wastewater to determine the effect on activity. The different ozonation doses used to prepare the DWW for the activity test trial were $0,200,400,800$ and $1200 \mathrm{mg} \mathrm{O} \cdot \mathrm{L}^{-1}$.

After $24 \mathrm{~h}$ of exposure to the five differently treated DWW, the effluents were decanted off and freshly prepared wastewaters were added. This cycle was repeated four times, thus over a period of $96 \mathrm{~h}$. The initial activity of the UASB granules was determined directly after the activation step and served as a control. The effect of the five different pre-treatments on granule activity was determined by measuring the activity directly after $96 \mathrm{~h}$ of exposure to the DWW.

Granules from each of the five exposure trials were subjected to an activity test. Duplicate granule samples $(3 \mathrm{~g})$ for three activity test mediums for each of the five exposure trials were placed in 20 $\mathrm{mL}$ glass vials (five treatments in duplicate for three activity mediums $=30$ vials). Each vial received $13 \mathrm{~mL}$ of the specific activity test medium. The three media used were the basic test media (BTM) (Table 1), glucose test media (GTM) and acetic acid test media (ATM). The BTM is not specific for any microbial group and was used to determine the starting granule activity. The GTM and ATM were used to measure the activity of the acidogens and acetoclastic methanogens respectively (Sigge, 2005). The composition of the GTM and ATM had BTM as base, with the addition of $2000 \mathrm{mg} . \mathrm{L}^{-1}$ glucose and $1000 \mathrm{mg} . \mathrm{L}^{-1}$ acetic acid respectively. The vials were sealed with butyl septa and capped with aluminium caps, before being incubated at $35^{\circ} \mathrm{C}$. After $5,10,25$ and $40 \mathrm{~h}$

\section{TABLE 1}

Composition of the basic test media (O'Kennedy, 2000) that was used to determine the starting granule activity.

\begin{tabular}{lc}
\hline Compound & $\begin{array}{c}\text { Concentration } \\
\left(\text { g. } \mathbf{L}^{-1}\right)\end{array}$ \\
\hline Glucose & 2.0 \\
Di-potassium hydrogen orthophosphate $\left(\mathrm{K}_{2} \mathrm{HPO}_{4}\right)$ & 1.0 \\
Potassium di-hydrogen orthophosphate $\left(\mathrm{KH}_{2} \mathrm{PO}_{4}\right)$ & 2.6 \\
Urea $\left(\left(\mathrm{NH}_{2}\right)_{2} \mathrm{CO}\right)$ & 1.1 \\
Ammonium chloride $\left(\mathrm{NH}_{4} \mathrm{Cl}\right)$ & 1.0 \\
Sodium sulphide $\left(\mathrm{Na}_{2} \mathrm{~S} \cdot 9 \mathrm{H}_{2} \mathrm{O}\right)$ & 0.1 \\
Magnesium chloride $\left(\mathrm{MgCl}_{2} \cdot 6 \mathrm{H}_{2} \mathrm{O}\right)$ & 0.1 \\
Yeast extract & 0.2 \\
pH & 7.1 \\
\hline
\end{tabular}

\section{TABLE 2}

Composition and variation of distillery wastewater at distillery outlet and after third pond.

\begin{tabular}{|c|c|c|}
\hline Parameter & $\begin{array}{l}\text { Distillery } \\
\text { outlet }\end{array}$ & $\begin{array}{l}\text { After third } \\
\text { pond }\end{array}$ \\
\hline $\mathrm{COD}\left(\mathrm{mg} . \mathrm{L}^{-1}\right)$ & $12609-22150$ & $3843-7614$ \\
\hline $\mathrm{pH}$ & $4.52-4.68$ & $6.75-8.51$ \\
\hline Alkalinity (as mg. $\mathrm{L}^{-1} \mathrm{CaCO}_{3}$ ) & $325-913$ & $1200-2850$ \\
\hline Phosphates (mg. $\left.\mathrm{L}^{-1}\right)$ & 254 & $209-245$ \\
\hline Polyphenols (mg.L -1 GAE) $^{-1}$ & $5.5-13.9$ & $3.0-4.7$ \\
\hline Total solids (g.L $\left.{ }^{-1}\right)$ & 11.68 & 7.46 \\
\hline Total volatile solids (g.L-1) & 8.33 & 3.62 \\
\hline Total suspended solids (g.L-1) & 1.43 & 0.57 \\
\hline Total volatile suspended solids (g.L $\left.\mathrm{L}^{-1}\right)$ & 1.30 & 0.44 \\
\hline
\end{tabular}

\section{TABLE 3}

Composition of DWW from third pond and after ozonation.

\begin{tabular}{|c|c|c|c|}
\hline Parameters & $\begin{array}{c}\text { Untreated } \\
\text { waste- } \\
\text { water }\end{array}$ & $\begin{array}{c}\text { Ozonated } \\
\text { waste- } \\
\text { water }\end{array}$ & $\begin{array}{c}\text { Change } \\
(\%)\end{array}$ \\
\hline COD (mg. $\left.\mathrm{L}^{-1}\right)$ & 2000 & 1260 & -37 \\
\hline $\mathrm{pH}$ & 8.21 & 8.40 & na \\
\hline Alkalinity (as mg $\mathrm{CaCO}_{3} \cdot \mathrm{L}^{-1}$ ) & 1150 & 1737 & 51 \\
\hline Phosphates $\left(\mathrm{mg} \mathrm{PO}_{4}{ }^{3-} \cdot \mathrm{L}^{-1}\right)$ & 92 & 122 & 33 \\
\hline Conductivity (mS) & 2.48 & 3.09 & 25 \\
\hline Polyphenols (mg.L ${ }^{-1}$ ) & 1.64 & 1.62 & -1.0 \\
\hline Total solids (g.L-1 $)$ & 2.70 & 3.55 & 31 \\
\hline Total volatile solids (g.L $\left.{ }^{-1}\right)$ & 0.65 & 1.15 & 77 \\
\hline Total suspended solids (g.L $\left.\mathrm{L}^{-1}\right)$ & 0.1 & 0.2 & 100 \\
\hline $\begin{array}{l}\text { Total volatile } \\
\left.\text { suspended solids (g.L }{ }^{-1}\right)\end{array}$ & 0.06 & 0.20 & 333 \\
\hline Colour $254 \mathrm{~nm}$ & 2.11 & 1.80 & na \\
\hline
\end{tabular}

na $=$ not applicable 


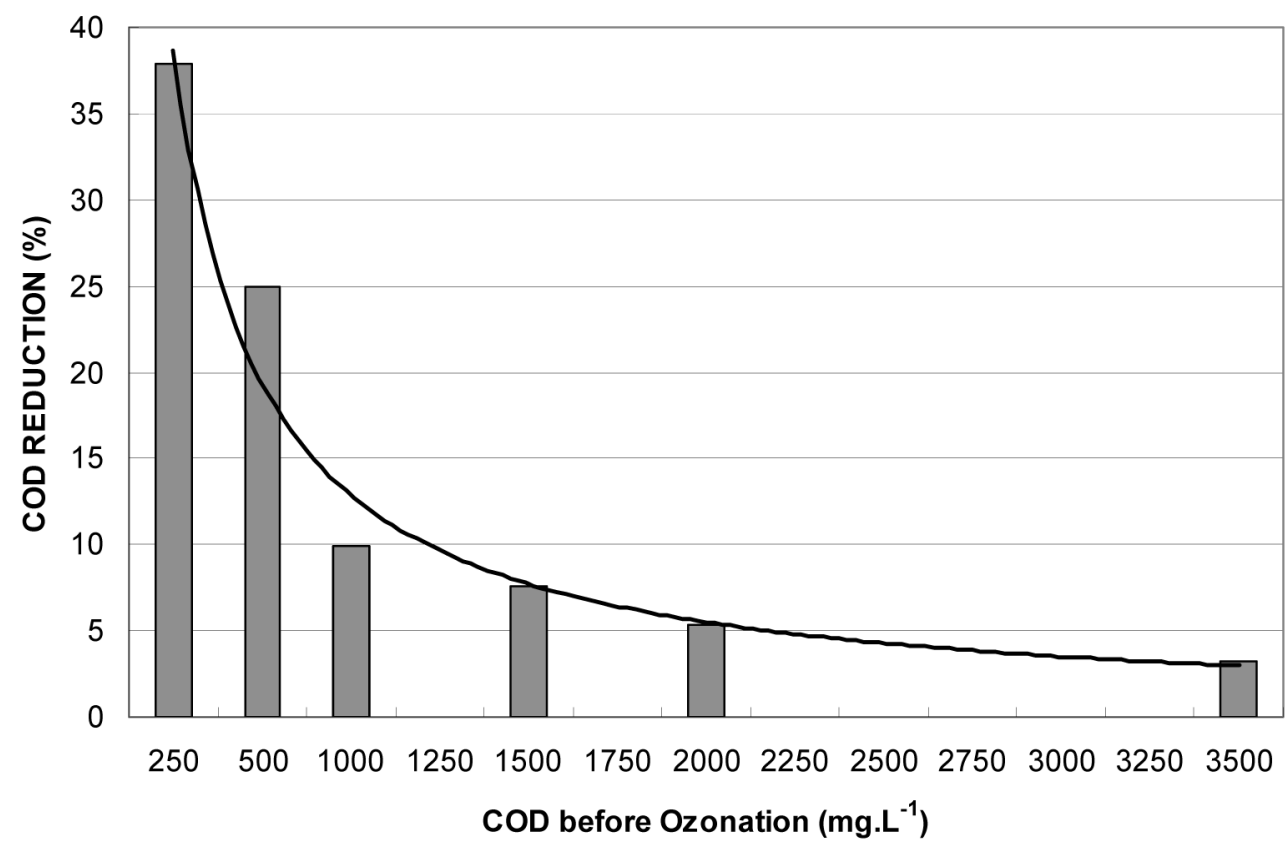

FIGURE 2

Percentage of COD reduction by different dilutions of distillery wastewater from third pond after a $400 \mathrm{mg} \mathrm{O}_{3} \cdot \mathrm{L}^{-1}$ dose.

incubation, biogas was sampled by inserting a free moving $10 \mathrm{~mL}$ syringe with a 12 gauge needle through the septa. This allowed the biogas volume to be determined. The biogas composition was determined by means of gas chromatography.

\section{RESULTS AND DISCUSSION}

\section{Characterisation of distillery wastewater streams}

The composition of DWW has been shown to vary considerably from day to day (Bezuidenhout et al., 2002). This is mainly due to the seasonal nature of the product, steam production, cooling, and floor and equipment wash down (Water Research Commission, 1993). The composition of the wastewater collected for this study during 2004 showed a wide variation. These variations are summarised in Table 2.

\section{Ozonation of distillery wastewater}

Due to the variation in the composition of the DWW shown in Table 2, an investigation was conducted to determine the efficiency of ozonation on DWW using a COD range (Fig. 2). It can be seen from the data in Fig. 2 that there is a decrease in the COD reduction efficiency of ozone as the wastewater COD increases. Fig. 2 also shows that the COD reduction of the wastewater decreased as the COD content increased. A 38\% reduction was obtained with the $250 \mathrm{mg}$ COD.L $\mathrm{L}^{-1}$ dilution, but this decreased to $3 \%$ for the $3500 \mathrm{mg}$ COD.L $\mathrm{L}^{-1}$ dilution. This would suggest that, as expected, the ozone is rapidly depleted in the oxidation process and no further hydroxyl radical formation occurs to increase the oxidation potential. The COD reductions achieved in the pre-wetland wastewater equate to an average COD reduction of $271 \mathrm{mg} \mathrm{COD.g} \mathrm{O}{ }_{3}^{-1}$. Therefore it can be calculated that $3.69 \mathrm{~g}$ of ozone will be needed to break down $1 \mathrm{~g}$ of COD in DWW wastewater from the third pond.

The data in Table 3 summarise the average effect of direct ozonation on the untreated wastewater. The ozonation resulted in a COD reduction of $37 \%$, reducing the COD from 2000 to 1260 mg. $\mathrm{L}^{-1}$. It is known that ozonation tends to increase alkalinity due to the precipitation of carbonates as a result of the mineralization of organic compounds (Alvarez et al., 2001), and this could be the reason for the increase in alkalinity from 1150 to $1737 \mathrm{mg} . \mathrm{L}^{-1}$. The precipitation of carbonates may also contribute to the increase in the content of solids, which increased from 2.70 to 3.55 g. $\mathrm{L}^{-1}$. Polyphenol reduction was only $1 \%$, and this is due to the fact that the initial levels in the untreated wastewater were very low. Colour decreased from a UV $254 \mathrm{~nm}$ absorbance level of 2.11 to 1.80 , and this can probably be attributed to ozone's ability to directly attack the $\mathrm{C}$ double bonds in aromatic and chromophoric molecules, leading to the formation of 'bleached' products, like aliphatic acids, ketones and aldehydes (Gottschalk et al., 2000).

\section{Activity Tests}

\section{Selection of granules}

A preliminary selection study was done to determine which type of granule would be the most suitable to study the effect of ozonation on the biodegradability of DWW. Granule activity was measured in terms of the production of biogas and methane. Cumulative biogas and methane volumes were measured and are shown in Tables 4 and 5 respectively.

From the data in Table 4 it can be seen that the granules from two different distilleries and the set from a winery were the most active in terms of biogas production for all three test evaluation media at 5, 10 and $40 \mathrm{~h}$.

In terms of methane production, the two distillery and the winery granules showed the highest activity at 5, 10 and $40 \mathrm{~h}$ for all three test media (Table 5). The differences between these three granule types, in terms of methane production, and the other granules were less pronounced.

From the data presented in Tables 4 and 5, it is evident that the highest cumulative biogas production occurred in the GTM, followed by the ATM. It is expected that the GTM, which is specific 
TABLE 4

Cumulative biogas volumes $(\mathrm{mL})$ produced over the $40 \mathrm{~h}$ incubation period by granules from various UASB reactor sources. Volumes are reported for the basic (BTM), glucose (GTM) and acetic acid test media (ATM). Volumes are averages of duplicate measurements (within $10 \%$ of each other).

\begin{tabular}{|c|c|c|c|c|c|}
\hline \multirow{2}{*}{ Granule source } & \multirow{2}{*}{ Test medium } & \multicolumn{4}{|c|}{ Incubation time (h) } \\
\hline & & 5 & 10 & 25 & 40 \\
\hline \multirow[t]{3}{*}{ Distillery 1} & BTM & 0.80 & 1.95 & 3.75 & 5.65 \\
\hline & GTM & 0.90 & 3.80 & 7.90 & 11.60 \\
\hline & ATM & 0.70 & 2.30 & 5.65 & 8.35 \\
\hline \multirow[t]{3}{*}{ Distillery 2} & ВТМ & 0.50 & 1.40 & 3.30 & 5.90 \\
\hline & GTM & 0.60 & 4.10 & 5.95 & 9.65 \\
\hline & ATM & 0.25 & 1.05 & 4.30 & 7.90 \\
\hline \multirow[t]{3}{*}{ Beer } & BTM & 0 & 0.57 & 1.02 & 1.02 \\
\hline & GTM & 0 & 2.30 & 3.95 & 3.95 \\
\hline & ATM & 0 & 0.45 & 0.85 & 0.85 \\
\hline \multirow[t]{3}{*}{ Mixture } & BTM & 0.65 & 0.65 & 0.80 & 0.90 \\
\hline & GTM & 0.80 & 1.60 & 2.40 & 3.00 \\
\hline & ATM & 0.35 & 0.55 & 0.65 & 0.75 \\
\hline \multirow[t]{3}{*}{ Fruit } & BTM & 0.70 & 1.0 & 1.25 & 2.05 \\
\hline & GTM & 0.80 & 2.85 & 4.15 & 4.85 \\
\hline & ATM & 0.60 & 1.20 & 1.40 & 2.05 \\
\hline \multirow[t]{3}{*}{ Winery } & BTM & 1.20 & 2.00 & 3.70 & 5.10 \\
\hline & GTM & 1.55 & 4.60 & 7.80 & 11.05 \\
\hline & ATM & 1.35 & 2.70 & 6.10 & 8.90 \\
\hline
\end{tabular}

* Highlighted values indicate higher cumulative biogas volumes produced by the two distillery and the winery granules in all three test media.

TABLE 5. Cumulative methane volumes $(\mathrm{mL})$ produced over the $40 \mathrm{~h}$ incubation period by granules from various UASB reactor sources. Volumes are reported for the basic (BTM), glucose (GTM) and acetic acid test media (ATM). Volumes are averages of duplicate measurements (within $10 \%$ of each other).

\begin{tabular}{|c|c|c|c|c|c|}
\hline \multirow{2}{*}{ Granule source } & \multirow{2}{*}{ Test medium } & \multicolumn{4}{|c|}{ Incubation time (h) } \\
\hline & & 5 & 10 & 25 & 40 \\
\hline \multirow[t]{3}{*}{ Distillery 1} & BTM & 0.078 & 0.265 & 0.478 & 0.706 \\
\hline & GTM & 0.090 & 0.836 & 1.932 & 2.947 \\
\hline & ATM & 0.073 & 0.266 & 0.918 & 1.210 \\
\hline \multirow[t]{3}{*}{ Distillery 2} & BTM & 0.019 & 0.105 & 0.373 & 0.614 \\
\hline & GTM & 0.019 & 0.744 & 1.327 & 2.332 \\
\hline & ATM & 0.007 & 0.064 & 0.460 & 0.731 \\
\hline \multirow[t]{3}{*}{ Beer } & BTM & 0.000 & 0.090 & 0.172 & 0.172 \\
\hline & GTM & 0.000 & 0.671 & 1.238 & 1.238 \\
\hline & ATM & 0.000 & 0.077 & 0.129 & 0.129 \\
\hline \multirow[t]{3}{*}{ Mixture } & ВТМ & 0.035 & 0.035 & 0.043 & 0.043 \\
\hline & GTM & 0.075 & 0.175 & 0.366 & 0.504 \\
\hline & ATM & 0.015 & 0.020 & 0.024 & 0.031 \\
\hline \multirow[t]{3}{*}{ Fruit } & BTM & 0.015 & 0.033 & 0.039 & 0.113 \\
\hline & GTM & 0.028 & 0.365 & 0.740 & 0.881 \\
\hline & ATM & 0.009 & 0.033 & 0.047 & 0.101 \\
\hline \multirow[t]{3}{*}{ Winery } & BTM & 0.061 & 0.142 & 0.354 & 0.454 \\
\hline & GTM & 0.082 & 0.819 & 1.778 & 2.398 \\
\hline & ATM & 0.076 & 0.277 & 0.672 & 1.008 \\
\hline
\end{tabular}

* Highlighted values indicate higher cumulative biogas volumes produced by the two distillery and the winery granules in all three test media.

for acidogens, should result in the highest production of gas. It is interesting to note that, for the two distillery and the winery granules, the ATM resulted in a higher production of biogas and methane than found for the BTM. As the ATM is specific for the acetoclastic methanogens, these results suggest that this methanogenic population is well developed and represented in these granules. Thus, the acidogens and the acetoclastic methanogens are active in these granules, making them suitable to be used in further activity tests to determine the effect of ozonation on the biodegradability of DWW.

Although the granules from the two distilleries and the winery UASB reactors were similar in cumulative production of biogas 
TABLE 6

Cumulative biogas volumes (mL) produced over the $40 \mathrm{~h}$ incubation period by granules exposed to distillery wastewater (DWW) treated with various concentrations of $\mathrm{O}_{3}$, and by a control, in the basic (BTM), glucose (GTM) and acetic acid test media (ATM). Volumes are averages of duplicate measurements (within $10 \%$ of each other).

\begin{tabular}{|c|c|c|c|c|c|}
\hline \multirow{2}{*}{ Granule treatment } & \multirow{2}{*}{ Test medium } & \multicolumn{4}{|c|}{ Incubation time (h) } \\
\hline & & 5 & 10 & 25 & 40 \\
\hline \multirow[t]{3}{*}{ Control* } & ВТМ & 0.80 & 1.95 & 3.75 & 5.65 \\
\hline & GTM & 0.90 & 3.70 & 7.80 & 11.50 \\
\hline & ATM & 0.70 & 2.30 & 5.65 & 8.35 \\
\hline \multirow[t]{3}{*}{$0 \mathrm{mg} \mathrm{O}_{3} \cdot \mathrm{L}^{-1}$} & BTM & 0.00 & 1.45 & 2.95 & 4.45 \\
\hline & GTM & 0.00 & 2.45 & 5.90 & 8.00 \\
\hline & ATM & 0.00 & 2.40 & 6.00 & 8.15 \\
\hline \multirow[t]{3}{*}{$200 \mathrm{mg} \mathrm{O}_{3} \cdot \mathrm{L}^{-1}$} & BTM & 0.00 & 1.75 & 3.85 & 5.35 \\
\hline & GTM & 0.00 & 2.80 & 6.60 & 9.00 \\
\hline & ATM & 0.00 & 2.10 & 5.10 & 7.55 \\
\hline \multirow[t]{3}{*}{$400 \mathrm{mg} \mathrm{O}_{3} \cdot \mathrm{L}^{-1}$} & BTM & 0.00 & 1.35 & 3.25 & 4.55 \\
\hline & GTM & 0.00 & 2.60 & 6.10 & 8.25 \\
\hline & ATM & 0.00 & 1.90 & 4.75 & 7.10 \\
\hline \multirow[t]{3}{*}{$800 \mathrm{mg} \mathrm{O}_{3} \cdot \mathrm{L}^{-1}$} & BTM & 0.00 & 0.80 & 2.85 & 4.45 \\
\hline & GTM & 0.00 & 2.05 & 5.75 & 7.65 \\
\hline & ATM & 0.00 & 1.30 & 4.40 & 6.55 \\
\hline \multirow[t]{3}{*}{$1200 \mathrm{mg} \mathrm{O}_{3} \cdot \mathrm{L}^{-1}$} & BTM & 0.00 & 0.95 & 2.55 & 3.85 \\
\hline & GTM & 0.00 & 2.00 & 5.60 & 7.80 \\
\hline & ATM & 0.00 & 1.40 & 4.25 & 6.25 \\
\hline
\end{tabular}

* Activity of control granules measured directly after activation step, thus no exposure to DWW.

\section{TABLE 7}

Cumulative methane volumes (mL) produced over the $40 \mathrm{~h}$ incubation period by granules exposed to distillery wastewater (DWW) treated with various concentrations of $\mathrm{O}_{3}$, and by a control, in the basic (BTM), glucose (GTM) and acetic acid test media (ATM). Volumes are averages of duplicate measurements (within $10 \%$ of each other).

\begin{tabular}{|c|c|c|c|c|c|}
\hline \multirow{2}{*}{ Granule treatment } & \multirow{2}{*}{ Test medium } & \multicolumn{4}{|c|}{ Incubation time (h) } \\
\hline & & 5 & 10 & 25 & 40 \\
\hline \multirow[t]{3}{*}{ Control* } & BTM & 0.078 & 0.265 & 0.478 & 0.706 \\
\hline & GTM & 0.090 & 0.783 & 1.879 & 2.894 \\
\hline & ATM & 0.073 & 0.266 & 0.503 & 0.795 \\
\hline \multirow[t]{3}{*}{$0 \mathrm{mg} \mathrm{O}_{3} \cdot \mathrm{L}^{-1}$} & BTM & 0.000 & 0.190 & 0.364 & 0.525 \\
\hline & GTM & 0.000 & 0.520 & 1.272 & 1.735 \\
\hline & ATM & 0.000 & 0.302 & 0.648 & 0.793 \\
\hline \multirow[t]{3}{*}{$200 \mathrm{mg} \mathrm{O}_{3} \cdot \mathrm{L}^{-1}$} & BTM & 0.000 & 0.323 & 0.616 & 0.835 \\
\hline & GTM & 0.000 & 0.673 & 1.711 & 2.378 \\
\hline & ATM & 0.000 & 0.214 & 0.459 & 0.557 \\
\hline \multirow[t]{3}{*}{$400 \mathrm{mg} \mathrm{O}_{3} \cdot \mathrm{L}^{-1}$} & BTM & 0.000 & 0.207 & 0.429 & 0.587 \\
\hline & GTM & 0.000 & 0.462 & 1.604 & 2.168 \\
\hline & ATM & 0.000 & 0.139 & 0.323 & 0.473 \\
\hline \multirow[t]{3}{*}{$800 \mathrm{mg} \mathrm{O}_{3} \cdot \mathrm{L}^{-1}$} & BTM & 0.000 & 0.088 & 0.399 & 0.580 \\
\hline & GTM & 0.000 & 0.406 & 1.336 & 1.841 \\
\hline & ATM & 0.000 & 0.130 & 0.342 & 0.528 \\
\hline \multirow[t]{3}{*}{$1200 \mathrm{mg} \mathrm{O}_{3} \cdot \mathrm{L}^{-1}$} & BTM & 0.000 & 0.088 & 0.296 & 0.450 \\
\hline & GTM & 0.000 & 0.285 & 1.112 & 1.674 \\
\hline & ATM & 0.000 & 0.121 & 0.337 & 0.477 \\
\hline
\end{tabular}

* Activity of control granules measured directly after activation step, thus no exposure to DWW. 
and methane gas, it was decided to use the granules from the Distillery 1 UASB reactor for further biodegradability studies.

\section{Effect of ozonation on the biodegradability of $\mathrm{DWW}$}

The effect of ozonated wastewater on the activity of anaerobic granules is shown using the cumulative production of biogas and methane of the granules in BTM, GTM and ATM (Tables 6 and 7).

The effect of DWW (ozonated and unozonated) can be seen when examining the cumulative biogas volume data presented in Table 6. The overall activity of the control granules, in terms of cumulative production of biogas in BTM, GTM and ATM, was higher than that of the granules exposed to the DWW over the $40 \mathrm{~h}$ incubation period. This is mainly due to the higher production of gas achieved after $5 \mathrm{~h}$ incubation (Table 6), and can be ascribed to the fact that the granules did not need to first acclimatise to the DWW. Cumulative biogas volumes in BTM, GTM and ATM for the granules exposed to ozonated DWW (200 and $400 \mathrm{mg} \mathrm{O}_{3} \cdot \mathrm{L}^{-1}$ ) were slightly higher than for the granules exposed to unozonated DWW ( $\left.0 \mathrm{mg} \mathrm{O}_{3} \cdot \mathrm{L}^{-1}\right)$. This would suggest that lower ozonation doses are beneficial to increasing the biodegradability of DWW.

As was the case with the cumulative biogas volumes, the effect of DWW (ozonated and unozonated) can be seen from the cumulative methane volumes listed in Table 7. The overall activity of the control granules, in terms of methane production in BTM, GTM and ATM, was higher than that of the granules exposed to DWW over the $40 \mathrm{~h}$ period. This is mainly due to the higher gas production achieved after $5 \mathrm{~h}$ incubation (Table 7), and can be ascribed to the fact that the granules did not need to first acclimatise to the DWW. It can also be seen from Table 7 that the overall activity of the granules exposed to ozonated DWW (200 and $\left.400 \mathrm{mg} \mathrm{O}_{3} \cdot \mathrm{L}^{-1}\right)$, in terms of methane production in BTM, GTM and ATM, was slightly higher than that of the granules exposed to unozonated DWW (0 $\mathrm{mg} \mathrm{O}_{3} \cdot \mathrm{L}^{-1}$ ) and to higher dosages of ozonation (800 and $1200 \mathrm{mg}$ $\left.\mathrm{O}_{3} \cdot \mathrm{L}^{-1}\right)$. This could again indicate a beneficial application in terms of biodegradability when applying low ozone doses to DWW.

Wine distillery wastewater is known to be toxic to microbial populations as a result of polyphenol concentrations that are often high (Alvarez et al., 2001; Martín et al., 2002). The DWW used in this study contained polyphenols (Table 3 ) and therefore it is reasonable to assume that the control granules should have exhibited the highest activity due to not being pre-exposed to polyphenolcontaining DWW. As expected, the cumulative volumes of biogas and methane showed that the control granules produce more biogas over the $40 \mathrm{~h}$ period for BTM, GTM and ATM (Tables 6 and 7). However, exposure of granules to DWW ozonated at 200 $\mathrm{mg} \mathrm{O} \cdot \mathrm{L}^{-1}$ resulted in a higher cumulative volume of biogas and methane than from the $0 \mathrm{mg} \mathrm{O} \cdot \mathrm{L}^{-1}$ dose.

From the data for cumulative biogas volumes (Tables 6 and 7), it would appear that lower ozone doses (i.e. 200 and $400 \mathrm{mg} \mathrm{O}_{3} . \mathrm{L}^{-1}$ ) were beneficial in increasing the biodegradability of DWW. It can also be deduced that DWW itself reduces the activity of granules, most likely due to the presence of polyphenols and other recalcitrant compounds in DWW. This is evident from the lower activity of the unozonated DWW compared to the control granules.

\section{CONCLUSIONS}

The DWW used in this study was characterised and found to show large variations over time. These variations were mainly ascribed to the impact of the production cycle of the distillery.
In this study, ozone was successfully utilised firstly to reduce COD levels in wine distillery wastewater, and secondly to increase the biodegradability of the wastewater. The ozonation of DWW was found to be effective in decreasing COD over a wide range of organic loads. An average COD reduction of $271 \mathrm{mg} \mathrm{COD.g} \mathrm{O}{ }_{3}^{-1}$ was found for wastewater from the distillery pond system.

Granule activity was measured to determine the effect of ozone on the biodegradability of DWW, and a low dose of ozone was found to increase the biodegradability of DWW. A suitable granule source was selected on the basis of activity in three activity media, after which further activity trials were carried out by exposing the granules to DWW that had received different doses of ozone. It was shown that a low dose of ozone (200 to $400 \mathrm{mg}$ $\left.\mathrm{O}_{3} \cdot \mathrm{L}^{-1}\right)$ increased granule activity in terms of biogas, methane production, and cumulative gas volumes. It is known that DWW is toxic to microbial populations due to high COD and polyphenol concentrations (Alvarez et al., 2001; Martín et al., 2002), and this would have an effect on a biological treatment method. Thus, if an increase in biodegradability can be shown, it could be argued that ozone would have potential as a pre-treatment to further biological systems.

In this study it was shown that the use of ozone has potential as a pre-treatment of DWW, but the effect of ozone still needs to be demonstrated on a more practical scale than just the activity tests. Therefore, the next step would be to investigate the use of ozone as a pre- and/or post-treatment in combination with a biological treatment, namely constructed wetlands.

\section{LITERATURE CITED}

Alvarez, P.M., Beltrán, F.J. \& Garcia-Araya, J.F., 2001. pH sequential ozonation of domestic and wine-distillery wastewaters. Water Res. 35(4), 929-936.

APHA. $1998\left(20^{\text {th }}\right.$ ed $)$. Standard methods for the examination of water and wastewater. American Public Health Association, Washington.

Andreozzi, A., Longo, G., Majone, M. \& Modesti, G., 1998. Integrated treatment of olive oil mill effluents (OME): Study of ozonation coupled with anaerobic digestion. Water Res. 32(8), 2357-2364.

Beltrán, F.J., García-Araya, J.F. \& Álvarez, P.M., 2000. Continuous flow integrated chemical (ozone). Activated sludge system treating combined agroindustrialdomestic wastewater. Environ. Prog. 19(1), 28-34.

Beltrán-Heredia, J., Dominguez, J.R., Perez, J.A. \& Torregrosa, J., 2001. Kinetics of the reaction between ozone and phenolic acids in agro-industrial wastewaters. Water Res. 35(4), 1077-1085.

Benitez, F.J., Beltrán-Heredia, J., Torregrosa, J. \& Dominguez J.R., 1999. Aerobic treatment of black olive wastewater and the effect on an ozonation stage. Bioprocess. Eng. 20, 355-361.

Bezuidenhout, S., Hayward, N., Lorenzen, L., Barnardt, N. \& Trerise, M., 2002. Environmental performance of SA wine industry - are we competitive? Wineland $71,79-81$.

Department of Water Affairs and Forestry, 2004 ( $1^{\text {st }}$ ed). National Water Resource Strategy. Department of Water Affairs and Forestry, Republic of South Africa.

Doğruel, S., Dulkadiroğlu, H., Germirli Babuna, F., Kabdaşli, I., Orhon, D. \& Sozen, S., 2002. Ozonation application in activated sludge systems for a textile mill effluent. Water Sci. Technol. 45(12), 305-313.

Duff, S.J.B., Sandhu, H. \& Zenaitis, M.G., 2002. Combined biological and ozone treatment of $\log$ yard run-off. Water Res. 36, 2053-2061.

Gottschalk, C., Libra, J.A. \& Saupe, A., 2000. Ozonation of water and waste water. Wiley-VCH Verlag, Weinheim.

Gulyas, H., Von Bismarck, R. \& Hemmerling, L., 1995. Treatment of industrial wastewaters with ozone.hydrogen peroxide. Water Sci. Technol. 32(7), 127-134. 
Martín, M.A., Rapsoso, F., Borja, R. \& Martín, A., 2002. Kinetic study of the anaerobic digestion of vinasse pre-treated with ozone, ozone plus ultraviolet light, and ozone plus ultraviolet light in the presence of titanium dioxide. Process Biochem. 37(7), 699-706.

McLachlan, T., 2004. Integration of a combined UASB-ozonation treatment system for cellar effluent degradation. Thesis, Stellenbosch University, Private Bag X1, 7602 Matieland (Stellenbosch), South Africa.

O'Kennedy, O.D., 2000. Application of biogranules in the anaerobic treatment of distillery effluents. Thesis, Stellenbosch University, Private Bag X1, 7602 Matieland (Stellenbosch), South Africa.

Sigge, G.O., 2005. Integration of anaerobic biological and advanced chemical oxidation processes to facilitate biodegradation of fruit canning and winery wastewaters. Dissertation, Stellenbosch University, Private Bag X1, 7602 Matieland (Stellenbosch), South Africa.
Singleton, V.L. \& Rossi, J.R., 1965. Colorimetry of total phenolics with phosphomolybdic-phosphotungistic acid reagents. Am. J. Enol. Vit. 16, 144-158.

Van Schoor, L., 2000. Bestuuropsies om negatiewe omgewingsimpakte by wynkelders te minimaliseer. Wynland 11, 97-100.

Van Schoor, L., 2005. Guidelines for the management of wastewater and solid waste at existing wineries. Winetech Report, South Africa.

Wang, Y.T., Pai, P.C. \& Latchaw, J.L., 1989. Effects of preozonation on the methanogenic toxicity of 2,5-dichlorophenol. Res. J. Water Poll. Cont. Fed. 61(3), 320-326.

Water Research Commission, 1993. Water and waste management in the wine industry. WRC Project No. 145 TT 51/90. Water Research Commission, Pretoria, South Africa. 